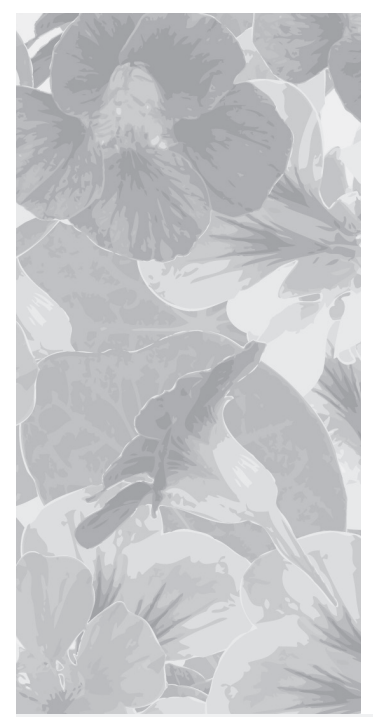

\title{
„Kosmeceutyki” i ,dermokosmetyki” - unikalna kategoria produktów do pielęgnacji skóry czy zwykły chwyt marketingowy?
}

\author{
"Cosmeceuticals" and "dermocosmetics" - a unique category of skin care \\ products or a plain marketing trick?
}

\author{
Sabina Zofia Rzeźnik, Katarzyna Kordus, Radosław Śpiewak \\ Zakład Dermatologii Doświadczalnej i Kosmetologii, Wydział Farmaceutyczny, Uniwersytet Jagielloński \\ Collegium Medicum, Kraków
}

Estetol Med Kosmetol 2012; 2(4): 101-103

DOI: http://dx.doi.org/10.14320/EMK.2012.021

\section{Streszczenie}

Osoby z problemami skórnymi zachęca się do korzystania z dostępnych w aptekach „kosmeceutyków” i „dermokosmetyków”, przy czym producenci starają się przekonać konsumentów, że jest to szczególna grupa produktów bliższa lekom niż "zwykłym” kosmetykom. Celem niniejszej pracy było przeanalizowanie genezy i znaczenia pojęć „kosmeceutyk” i „dermokosmetyk" a także ich statusu prawnego w świetle legislacji polskiej i międzynarodowej. Materiat i metody: Przegląd literatury naukowej i obowiązujących aktów prawnych odnoszących się do omawianego zagadnienia. Wyniki: Termin „kosmeceutyk” zaproponowat Reeds w 1961 roku, a Kligman go rozpowszechnit. Wedtug tych autorów „kosmeceutyk” to kosmetyk wpływający na procesy fizjologiczne skóry i wspomagający leczenie chorób skóry. Termin „dermokosmetyk” w indeksowanej literaturze naukowej został po raz pierwszy użyty przez Sellesa i wsp. w 1990 roku. Jedna z popularnych definicji wyjaśnia, że "dermokosmetyk" to specjalny kosmetyk przeznaczony na określone dolegliwości skórne i dla ściśle określonych typów skóry, tworzony we współpracy z dermatologami i rozprowadzany wyłącznie w aptekach. Definicje "kosmeceutyków” i „dermokosmetyków” nie są w żadnym kraju na świecie uregulowane prawnie, co otwiera pole dla nieporozumień i nadużyć. Wnioski: Terminy „kosmeceutyk” czy „dermokosmetyk” nie istnieją w obecnym porządku prawnym, wydaje się nadto, że są to pojęcia z zakresu raczej marketingu niż nauki. Produkty sprzedawane pod tymi określeniami zwykle nie są ani bezpieczniejsze, ani skuteczniejsze od „zwykłych” kosmetyków. Dlatego do kosmetyków propagowanych przez producentów jako „kosmeceutyki” czy „dermokosmetyki” należy podchodzić z należnym sceptycyzmem i krytycyzmem.

Stowa kluczowe: kosmeceutyk, dermokosmetyk, kosmetyk, apteka, lek, definicje prawne, marketing

\section{Abstract}

People with skin problems are frequently encouraged to use "cosmeceuticals" and "dermocosmetics" available from chemists' shops, with producers trying to convince the consumers that products referred to in this way would be more like therapeutic drugs, rather than "ordinary" cosmetics. The aim of this study was to analyse the genesis and meaning of the terms "cosmeceutical" and "dermocosmetic", as well as their legal standing in the light of Polish and international law. Material and methods: A review of scientific literature and legal regulations relevant to the discussed topics. Results: The term "cosmeceutical" was proposed by Reeds in 1961 and propagated by Kligman. According to these authors, a "cosmeceutical" is a cosmetic product that influences the physiological processes in the skin and supports the therapy of skin diseases. The term "dermocosmetics" was used for the first time in the indexed scientific literature by Selles et al. in 1990. One of the popular definitions states that a "dermocosmetic" is a special product dedicated to strictly-defined skin problems in strictly-defined skin types, which is engineered in collaboration with dermatologists and distributed only via chemists" shops. The terms "cosmeceuticals" and "dermocosmetics" are not legally defined in any country, which leaves room for misunderstanding and misuse. Conclusions: The terms "cosmeceuticals" and "dermocosmetics" are absent from the present legal order; moreover, they also seem to belong to the realm of marketing rather than science. Products sold under these appellations are neither safer, nor more effective than "ordinary" cosmetics. Therefore, products marketed as "cosmeceuticals" and "dermocosmetics" should be regarded with due scepticism and criticism.

Keywords: cosmeceuticals, dermocosmetics, cosmetics, chemists' shop, pharmacy, medicinal drug, legal definitions, marketing

Copyright $\odot 2012$ the Authors (text) and Radosław Śpiewak (layout \& journal compilation). All rights reserved.

„Kosmeceutyki” wydają się robić zawrotną karierę we współczesnej kosmetologii i dermatologii [1]. Termin „kosmeceutyk” zaproponował w 1961 roku Raymond Reed - członek-założyciel Towarzystwa Chemii Kosmetycznej w USA, zaś ideę Reeda rozpropagował pod koniec lat 1970-ych Albert M. Kligman. Według Reeda i Kligmana „kosmeceutyk” to kosmetyk wpływający na procesy fizjologiczne skóry i wspomagający leczenie chorób skóry [2]. Produkty te są przeznaczane do stosowania w określonych problemach estetycznych [3]. Twórcy tego terminu twierdzą, że dzięki skutecznemu, bezpiecznemu, stabilnemu oraz nowatorskiemu działaniu mają one lepiej chronić skórę [4,5]. Jednak Stephen H. McNamara z większą dozą sceptycyzmu podkreśla, że „kosmeceutyk” to „(...) nieoficjalnie używane określenie wyrobów kosmetycznych, którym w promocji i reklamie przypisuje się właściwości pozytywnego wplywania na stan skóry, tzn. takich wyrobów 
kosmetycznych, które zapewniaja korzystne oddziatywanie na skórę o charakterze leczniczym" [6]. Wydaje się, że to głównie natarczywość reklamy i marketingu powoduje, że konsumenci chętniej sięgają właśnie po produkty określane mianem „kosmeceutyków”, a nie po zwykłe kosmetyki. Termin „dermokosmetyk” został po raz pierwszy w indeksowanej literaturze naukowej użyty przez Sellesa i wsp. w 1990 roku [7]. Jest on stosowany rzadziej od terminu „kosmeceutyk” i poświęcono mu zdecydowanie mniej publikacji. Jedna z popularnych definicji wyjaśnia, że ,dermokosmetyk” to specjalny kosmetyk przeznaczony na określone dolegliwości skórne i dla ściśle określonych typów skóry, tworzony we współpracy z dermatologami i rozprowadzany wyłącznie w aptekach [8]. Sugeruje się, że pojęcia "kosmeceutyk” i „dermokosmetyk” mają oznaczać ,aktywne kosmetyki”, czyli produkty, które rzekomo łączą właściwości kosmetyku i leku. Ustawa o kosmetykach stanowi jednak, że ,kosmetykiem jest każda substancja lub preparat przeznaczone do zewnętrznego kontaktu z ciałem człowieka: skóra, włosami, wargami, paznokciami, zewnętrznymi narzadami płciowymi, zębami i błonami śluzowymi jamy ustnej, których wytaccznym lub podstawowym celem jest utrzymanie ich $w$ czystości, pielegnowanie, ochrona, perfumowanie, zmiana wygladu ciała lub upiększenie zapachu" [9]. Natomiast Ustawa Prawo farmaceutyczne definiuje, że „Produktem leczniczym jest substancja lub mieszanina substancji, przedstawiona jako posiadajaca właściwości zapobiegania lub leczenia chorób wystepujacych u ludzi lub zwierzat lub podawana $w$ celu postawienia diagnozy lub w celu przywrócenia, poprawienia lub modyfikacji fizjologicznych funkcji organizmu poprzez działanie farmakologiczne, immunologiczne lub metaboliczne" [10]. Dany produkt nie może być jednocześnie kosmetykiem i lekiem [6]. Tak więc termin ,kosmeceutyk” nie ma znaczenia w świetle prawa, a produkt określany takim mianem podlega prawodawstwu dotyczącemu kosmetyków [3]. Skoro zatem regulacje dla „kosmeceutyku” i ,dermokosmetyku” są identyczne jak dla każdego innego kosmetyku, nie ma jakichkolwiek gwarancji, że produkty oznaczone tymi terminami będą pod jakimś względem lepsze od zwykłych produktów kosmetycznych. A co za tym idzie, „kosmeceutyk” czy „dermokosmetyk” wcale nie musi być wolny od substancji potencjalnie niebezpiecznych, nie musi również przewyższać „zwykłych” kosmetyków zawartością składników aktywnych. Podobny problem opisano wcześniej w odniesieniu do tzw. „emolientów" - produktów sprzedawanych w aptekach jako specjalne preparaty do pielęgnacji skóry w chorobach alergicznych, które w istocie nie różniły składem się od pospolitych produktów drogeryjnych, a 79\% aptecznych „emolientów” zawierało substancje o znanym potencjale uczulającym [11].

Składnikami czynnymi kosmetyku są substancje, które wpływają na procesy biochemiczne lub fizykochemiczne, a przez to na fizjologię skóry, błon śluzowych i ich przydatków [12]. „Kosmeceutyki” i „dermokosmetyki" to jak mniemają autorzy licznych publikacji produkty, które obejmują szeroką kategorię substancji przeciwutleniających, czynników wzrostu, peptydów, czynników przeciwzapalnych, polisacharydów, środków rozjaśniających, a także zawierających retinol, ubichinon (koenzym Q10), ceramidy, pantenol, kinetynę, witaminy A, E, C oraz $\alpha$-hydroksykwasy i $\beta$-hydroksykwasy, które wychodzą poza zakres funkcji upiększających i istotnie wpływają na strukturę i funkcję skóry $[4,13]$. Co ciekawe, niektóre dopuszczone prawem składniki kosmetyków są zarazem legalnymi substancjami aktywnymi leków. Najczęściej stosowaną w kosmetykach przeciwtrądzikowych substancją aktywną jest kwas salicylowy [14], który jest też aktywnym składnikiem szeregu produktów leczniczych o działaniu keratolitycznym oraz przeciwzapalnym (inhibitor cyklooksygenazy w kaskadzie kwasu arachidonowego) $[15,16]$. W kosmetykach wykorzystuje się ponadto piroglutaminian cynku, który hamuje aktywność 5-alfa reduktazy - enzymu przekształcającego testosteron w silnie stymulujący gruczoły łojowe dihydroksytestosteron [17]. Producenci „kosmeceutyków” chętnie sięgają po nikotynamid, którego aktywność przeciwtrądzikowa w radomizowanych badaniach klinicznych okazała się porównywalna z miejscowym preparatem antybiotyku klindamycyny [18]. Jak z tego wynika, stosowane przez producentów substancje aktywne w „kosmeceutykach” i ,dermokosmetykach" mogą niekiedy faktycznie wykazywać działanie z pogranicza kosmetyku i leku, pozostając przy tym w zakresie legislacji dla kosmetyków. Wcześniejsze analizy produktów przeciwtrądzikowych wykazały jednak, iż „kosmeceutyki” i „,dermokosmetyki" mimo większej liczby substancji aktywnych nie gwarantują większej skuteczności i bezpieczeństwa w porównaniu z kosmetykami z drogerii, gdyż w obu grupach zdarzają się produkty zupełnie pozbawione substancji aktywnych, natomiast produkty dostępne w aptece paradoksalnie mogą zawierać więcej składników ,problematycznych” [14,19].

Wprawdzie prawodawstwo Japonii i Korei rozróżnia trzy kategorie produktów: produkty kosmetyczne, kosmetyki funkcjonalne (,quasi-lek”) oraz leki, to w żadnym kraju na świecie nie wyróżnia się ustawowo „kosmeceutyków” czy „dermokosmetyków” [20]. Wydaje się, że terminy te służą głównie producentom do manipulowania konsumentami [21]. Problem „produktów pogranicza”, w tym również „kosmeceutyków” i „dermokosmetyków” budzi sporo emocji. Podkreśla się, że znowelizowana w marcu 2007 roku zgodnie z dyrektywą UE 2004/27/WE Ustawa Prawo farmaceutyczne stanowi, że produkt który jednocześnie spełnia kryteria produktu leczniczego oraz innego rodzaju produktu (m. in. kosmetyku) podlega przepisom Prawa farma- 
ceutycznego [22]. Wszystkie opublikowane do tej pory orzeczenia Europejskiego Trybunału Sprawiedliwości w sprawie klasyfikacji ,,produktów pogranicza” uznawały takie produkty za leki [23]. Jeżeli dochodzi do sporów na temat klasyfikacji produktów, władze oraz sądy każdego państwa członkowskiego UE mogą rozstrzygać dany problem indywidualnie, jednak z uwzględnieniem wytycznych Komisji Europejskiej dotyczących rozgraniczenia między Dyrektywą Kosmetyczną 76/768/WE a Dyrektywą dotyczącą Produktów Leczniczych 2001/83/WE [23]. Należy przy tym pamiętać, że proces rejestracji produktu jako leku jest znacznie bardziej kosztowny i czasochłonny, co z reguły odstrasza producentów. Dlatego dostępne w aptekach produkty występujące pod nazwą „kosmeceutyków” czy „dermokosmetyków” to z reguły „zwykłe” kosmetyki, które podlegają takim samym zasadom rejestracji, dopuszczenia do obrotu i produkcji jak każdy inny produkt kosmetyczny.

\section{Wnioski}

Pojęcia „kosmeceutyk” i „dermokosmetyk” nie istnieją w obecnym porządku prawnym i są to terminy zakresu raczej marketingu niż nauki. Produkty sprzedawane pod tymi określeniami zwykle nie są ani bezpieczniejsze, ani skuteczniejsze od „zwykłych” kosmetyków. Dlatego do kosmetyków określanych przez producentów jako „kosmeceutyki” czy „dermokosmetyki” należy podchodzić z należnym sceptycyzmem i krytycyzmem.

\section{Piśmiennictwo}

1. Dover JS: Cosmeceuticals: A practical approach. Skin Therapy Lett Pharmacist Edition 2008;3(1):1-3.

2. Newburger AE: Cosmeceuticals: myths and misconceptions. Clin Dermatol 2009;27(5):446-52.

3. Wojnowska D: Kosmeceutyki w pielęgnacji skóry kobiet w okresie menopauzalnym. Przegląd Menopauzalny 2011; 4: 338-42.

4. Padma PJ, Karthka K: Cosmeceuticals - an evolution. Int J Chem Tech 2009; 4: 1217-23.

5. Green JB, Metelitsa AI: Introduction. Cosmeceuticals: current trends and market analysis. Semin Cutan Med Surg 2011;30(3):139-40.

6. McNamara SH: FDA regulation of cosmeceuticals. U.S. cosmetic and drug regulations pertinent to the cosmeceutical issue. Cosmetics and Toiletries 1997;112(3): 41-5.

7. Sellés E, Jiménez I, Fresno M: Rheological behaviour of 'Cérat Cosmétique, Ph. F.'. Int J Cosmet Sci 1990; 12(2): 55-62.

8. Śpiewak R: Dermokosmetyk. W: dermatopedia.pl. URL: http://www.dermatopedia.pl/index.php/indekshasel/indeks-a-i/d/140-dermokosmetyk (dokument elektroniczny, stan na dzień 3.04.2012).

9. Ustawa z dnia 30 marca 2001 roku o kosmetykach. Dziennik Ustaw 2001; Nr 42, poz. 473.
10. Ustawa z dnia 6 września 2001 roku Prawo farmaceutyczne. Dziennik Ustaw 2001; Nr 126, poz. 1381: Art. 2 pkt. 32.

11. Kordus K, Śpiewak R. Emolienty z apteki - pomoc czy zagrożenie dla chorych na wyprysk? Alergia Astma Immunologia 2012;17(3):147-53.

12. Marzec A: Podział surowców ze względu na ich działanie w kosmetykach W: Chemia kosmetyków. Dom Organizatora TNOiK, Toruń 2009: 69.

13. Choi CM, Berson DS: Cosmeceuticals. Semin Cutan Med Surg 2006;25(3):163-8.

14. Rzeźnik SZ, Kordus K, Śpiewak R: Kosmetyki do cery trądzikowej dostępne w aptekach: Analiza deklarowanych składników aktywnych oraz substancji potencjalnie niebezpiecznych. Estetol Med Kosmetol 2012;2(3): 77-82.

15. Akhavan A, Bershad S: Topical acne drugs. Review of clinical properties, systemic exposure, and safety. Am J Clin Dermatol 2003; 4(7):473-92.

16. Placek W, Romańska-Gocka K, Grzanka A: Leczenie miejscowe trądziku. Przegl Dermatol 2011; 98:4 42-8.

17. Szpanka J: Surowce do zadań specjalnych. Przemysł Kosmetyczny 2011; 2: 36-9.

18. Shalita AR, Smith JG, Parish LC, Sofman MS, Chalker DK: Topical nicotinamide compared with clindamycin gel in the treatment of inflammatory acne vulgaris. Int J Dermatol 1995;34(6):434-7.

19. Macioł D, Kordus K, Śpiewak R: Kosmetyki do cery trądzikowej dostępne w drogeriach: Analiza deklarowanych składników aktywnych oraz substancji potencjalnie niebezpiecznych. Estetol Med Kosmetol 2012;2(3): 83-8.

20. Lintner K, Mas-Chamberlin C, Mondon P, Peschard O, Lamy L: Cosmeceuticals and active ingredients. Clin Dermatol 2009;27(5):461-8.

21. Draelos ZD: Cosmeceuticals: undefined, unclassified, and unregulated. Clin Dermatol 2009;27(5):431-4.

22. Wieniawski W: Problemy kontroli nad produktami „pogranicza“" (suplementy diety, dermokosmetyki, antyseptyki) IV Forum Farmacji Przemysłowej, Kościelisko 2008. Farmacja Polska 2009; 65(4): 259-68.

23. Dobre Praktyki Deklaracji Marketingowych i Reklamy Kosmetyków. Polski Związek Przemysłu Kosmetycznego, Warszawa 2011

\section{Finansowanie i konflikt interesów}

Autorzy deklarują niewystępowanie konfliktu interesów $\mathrm{w}$ odniesieniu do treści zawartych w niniejszej pracy.

\section{Adres do korespondencji}

dr hab. med. Radosław Śpiewak, profesor UJ

Zakład Dermatologii Doświadczalnej i Kosmetologii

Wydział Farmaceutyczny UJ

ul. Medyczna 9, 30-688 Kraków

Tel.: 1262058 30, Fax: 126205645

E-mail: spiewak.eu@gmail.com

Data złożenia: 17.07.2012

Data akceptacji: 18.09 .2012 